\title{
Gastric secretion of platelet activating factor and precursors in healthy humans: effect of pentagastrin
}

\author{
I Sobhani, Y Denizot, S Hochlaf, D Rigaud, J Vatier, J Benveniste, M J Lewin, M Mignon
}

\begin{abstract}
The release of platelet activating factor (PAFACETHER or PAF) and its precursors in the gastric lumen was assessed in 13 normal subjects in basal condition and after stimulation by gastrin. Acid, pepsin, and sialic acid outputs were determined under the same conditions. Gastric juice was collected using a nasogastric tube after overnight fast in basal condition for 60 minutes, then under pentagastrin infusion $(6 \mu \mathrm{g} / \mathrm{kg} / \mathrm{hr}$ for 60 minutes). Platelet activating factor was detected at low concentration in 4/13 subjects under basal condition (mean (SEM) $1.2(0.6) \mathrm{pg} / \mathrm{hr}$ ) while high concentrations of lyso platelet activating factor $(6 \cdot 1)(1 \cdot 8)$ $\mu \mathrm{g} / \mathrm{hr}$ ) and of alkyl-acyl-glycerophosphocholine (AAGPC) $(11.5$ (3) $\mu \mathrm{g} / \mathrm{hr}$ ) were found in 13 and 11 subjects, respectively. Platelet activating factor was not detected during pentagastrin infusion, while lyso platelet activating factor and alkyl-acyl-glycerophosphocholine were detected in 13 and in 12 subjects, respectively. Compared with the basal condition these platelet activating factor precursors increased significantly $(p<0.001)$ going up to fivefold baseline $(31.8(6.8) \mu \mathrm{g} / \mathrm{hr}$ and $53(9.3) \mu \mathrm{g} / \mathrm{hr}$ respectively) in response to pentagastrin. There was a positive correlation between platelet activating factor precursors and acid or pepsin output but not between platelet activating factor precursors and sialic acid. As sialic acid may be considered an index of mucus glycoprotein degradation, it seems that gastrin stimulation of gastric epithelial cells results in a concomittant secretion of platelet activating factor precursors, acid, and pepsin irrespective of mucus glycoprotein degradation.
\end{abstract}

(Gut 1993; 34: 1051-1056)

Service de

Gastroentérologie, Hôpital Bichat, Paris, France

I Sobhani

S Hochlaf

D Rigaud

J Vatier

M Mignon

INSERM U 200,

Clamart, France

Y Denizot

J Benveniste

INSERM U 10, Paris, France

M J Lewin

Correspondence to: Dr I Sobhani, Service d'Hépto-Gastroentérologie, CHU Bichat, 46 Rue $\mathrm{H}$ Huchard, 75877 Paris Cedex 18, France. monocytes, macrophages, platelets, eosiniophils, vascular endothelial cells, and several cancer cell lines. ${ }^{3-8}$ Two metabolic steps play a part in platelet activating factor biosynthesis: firstly, phospholipase $A_{2}$ acts on membrane choline containing alkyl phospholipids such as alkylacyl-glycerophosphocholine (AAGPC) resulting in the production of lyso platelet activating factor, that is - 1-O-alkyl-sn-glycero-3-phosphocholine; secondly, this lyso platelet activating factor is acetylated by an acetyltransferase to yield the biologically active molecule.$^{89}$ Platelet activating factor causes gastrointestinal mucosal injury and ischemic bowel necrosis. ${ }^{10-12}$ Recently we described the presence of platelet activating factor in the gastric juice in disease conditions in humans ${ }^{13}$ and in the physiological condition in the cat. $^{14}$ Several hormones may stimulate platelet activating factor biosynthesis in vitro. ${ }^{91}$ In the cat, histamine stimulates both gastric acid and platelet activating factor in vivo. ${ }^{14}$ Gastrin is one of the most important physiological regulatory factors of gastric secretion that reduces gastric platelet activating factor output in patients suffering from oesophagitis, or gastroduodenal ulcers, or both. ${ }^{13}$ In this study we aimed at the investigation of platelet activating factor synthesis in the gastric juice of normal healthy volunteers in vivo, in basal condition, and in response to pentagastrin. We assessed gastric platelet activating factor, lyso platelet activating factor, and AAGPC outputs and analysed correlations between platelet activating factor and precursors, and gastric acid, pepsin, and mucus linked sialic acid.

\section{Patients and methods}

\section{SUBJECTS}

Thirteen male volunteers (ages ranging from 20 to 53 , mean 29 years) were investigated. They had no previous medical history of gastrointestinal, inflammatory, hypersensitivity, or neoplastic diseases, and none was taking drugs; two of 13 were smokers (subjects 3 and 6, Table). All individuals gave informed consent and had gastric juice analysis: after an overnight fast, a nasogastric tube was positioned in the gastric antrum with endoscopy guidance and its correct position checked by the water recovery test with the subjects in semirecumbent position. The gastric juice was collected by gentle manual aspiration during 135 minutes. The first 15 minute sample was discarded. Then basal samples were collected every 15 minutes for one hour followed by four 15 minute samples collected during intravenous infusion of pentagastrin $(6 \mu \mathrm{g} / \mathrm{kg} / \mathrm{hr})$. Each sample was submitted to assay for platelet activating factor, platelet activating factor precursors, acid, pepsin, choline, and $\mathrm{N}$-acetylneuraminic acid (NANA).
MEASUREMENT OF PLATELET ACTIVATING FACTOR AND PRECURSORS

For extraction of platelet activating factor and platelet activating factor precursors, gastric juice samples were immediately mixed on ice with $100 \%$ ethanol ( 1 vol: $4 \mathrm{vol}$ ) and kept at $-20^{\circ} \mathrm{C}$ until platelet activating factor assay. Platelet activating factor concentration was measured in 
Concentration ${ }^{\star}$ of acid, platelet activating factor $(P A F), P A F$ precursors, pepsin, and NANA in gastric lumen in basal condition and under pentagastrin infusion in 13 healthy subjects

\begin{tabular}{|c|c|c|c|c|c|c|c|c|c|c|c|c|c|c|}
\hline $\begin{array}{l}\text { Subject } \\
\text { No }\end{array}$ & $\begin{array}{l}=V o l \\
B \\
(m l)\end{array}$ & $\begin{array}{l}=V o l \\
P G \\
(m l)\end{array}$ & $\begin{array}{l}\text { Acid } \\
(\mathrm{mmol} / \mathrm{l}) \\
B\end{array}$ & $\begin{array}{l}\text { Acid } \\
(\mathrm{mmol} / \mathrm{l}) \\
P G\end{array}$ & $\begin{array}{l}P A F \\
(p g / m l) \\
B\end{array}$ & $\begin{array}{l}P A F \\
(p g / m l) \\
P G\end{array}$ & $\begin{array}{l}\text { Lyso } \\
P A F \\
(n g / m l) \\
B\end{array}$ & $\begin{array}{l}\text { Lyso } \\
P A F \\
(n g / m l) \\
P G\end{array}$ & $\begin{array}{l}A A G P C \\
(\mu g / m l) \\
B\end{array}$ & $\begin{array}{l}A A G P C \\
(\mu g / m l) \\
P G\end{array}$ & $\begin{array}{l}\text { Pepsin } \\
(U P / m l) \\
B\end{array}$ & $\begin{array}{l}\text { Pepsin } \\
(U P / m l) \\
P G\end{array}$ & $\begin{array}{l}\text { NANA } \\
(\mu g / m l) \\
B\end{array}$ & $\begin{array}{l}\text { NANA } \\
(\mu g / m l) \\
P G\end{array}$ \\
\hline $\begin{array}{l}1 \\
2 \\
3 \\
4 \\
5 \\
6 \\
7 \\
8 \\
9 \\
10 \\
11 \\
12 \\
13 \\
\text { Mean } \\
\text { (SEM) }\end{array}$ & $\begin{array}{r}121 \\
64 \\
30 \\
41 \\
28 \\
47 \\
146 \\
44 \\
37 \\
37 \\
54 \\
21 \\
28 \\
53 \cdot 7 \\
(10)\end{array}$ & $\begin{array}{c}329 \\
254 \\
116 \\
134 \\
211 \\
207 \\
289 \\
162 \\
193 \\
211 \\
168 \\
133 \\
87 \\
192 \\
(19)\end{array}$ & $\begin{array}{l}66 \\
59 \\
50 \\
49 \\
48 \\
45 \\
71 \\
43 \\
89 \\
62 \\
62 \\
48 \\
67 \\
58 \\
(4)\end{array}$ & $\begin{array}{c}112 \\
108 \\
133 \\
114 \\
110 \\
123 \\
117 \\
132 \\
130 \\
137 \\
147 \\
56 \\
123 \\
119 \\
(6)\end{array}$ & $\begin{array}{l}0 \\
0 \\
0.053 \\
0 \\
0 \\
0.078 \\
0 \\
0 \cdot 070 \\
0 \cdot 20 \\
0 \\
0 \\
0 \\
0 \\
0.03 \\
\quad(0.01)\end{array}$ & $\begin{array}{l}0 \\
0 \\
0 \\
0 \\
0 \\
0 \\
0 \\
0 \\
0 \\
0 \\
0 \\
0 \\
0 \\
0 \\
0\end{array}$ & $\begin{array}{l}0.03 \\
0.10 \\
0.12 \\
0.03 \\
0.04 \\
0.09 \\
0.16 \\
0.02 \\
0.05 \\
0.10 \\
0.28 \\
0.08 \\
0.09 \\
0.09 \\
(0.01)\end{array}$ & $\begin{array}{l}0.06 \\
0.20 \\
0.46 \\
0.19 \\
0.21 \\
0.10 \\
0.05 \\
0.40 \\
0.13 \\
0.15 \\
0.37 \\
0.04 \\
0.05 \\
0.18 \\
(0.04)\end{array}$ & $\begin{array}{l}0 \\
0.31 \\
0.17 \\
0.23 \\
0 \cdot 16 \\
0.01 \\
0 \cdot 12 \\
0.22 \\
0 \cdot 18 \\
0 \cdot 19 \\
0 \cdot 17 \\
0.02 \\
0 \quad \\
0.14 \\
\quad(0.03)\end{array}$ & $\begin{array}{l}0.32 \\
0.32 \\
0.57 \\
0.51 \\
0.47 \\
0.04 \\
0.14 \\
0.32 \\
0.26 \\
0.13 \\
0.53 \\
0.14 \\
0 \\
0.29 \\
\quad(0.05)\end{array}$ & $\begin{array}{l}6 \cdot 0 \\
4 \cdot 0 \\
5 \cdot 0 \\
3 \cdot 3 \\
5 \cdot 6 \\
5 \cdot 0 \\
4 \cdot 0 \\
3 \cdot 7 \\
5 \cdot 0 \\
4 \cdot 9 \\
5 \cdot 0 \\
6 \cdot 1 \\
6 \cdot 0 \\
5 \\
(0.01)\end{array}$ & $\begin{array}{l}5 \cdot 1 \\
4 \cdot 1 \\
5 \\
3 \cdot 9 \\
6 \cdot 5 \\
5 \cdot 2 \\
5 \cdot 5 \\
4 \cdot 6 \\
5 \cdot 4 \\
5 \cdot 2 \\
5 \cdot 3 \\
6 \cdot 4 \\
6 \cdot 4 \\
5 \quad(0 \cdot 1)\end{array}$ & $\begin{array}{c}8 \\
9 \\
5 \\
8 \\
7 \\
10 \\
10 \\
17 \\
10 \\
10 \\
12 \\
12 \\
6 \\
10 \\
(1)\end{array}$ & $\begin{array}{l}9 \\
10 \\
12 \\
19 \\
12 \\
10 \\
14 \\
27 \\
17 \\
17 \\
15 \\
17 \\
10 \\
14 \\
(2)\end{array}$ \\
\hline p & \multicolumn{2}{|c|}{$<0.01$} & \multicolumn{2}{|c|}{$<0.01$} & & & \multicolumn{2}{|c|}{$<0.05$} & \multicolumn{2}{|c|}{$<0.05$} & \multicolumn{2}{|c|}{$<0.05$} & \multicolumn{2}{|c|}{$<0.01$} \\
\hline
\end{tabular}

${ }^{\star}$ Mean value of four 15 minute concentrations; = Vol: volume as sum of four 15 minute gastric liquid aspirated; B: basal condition; PG: pentagastrin infusion; AAAGPC: akly-acyl glycerophosphocholine; Student's $t$ paired test with significance set at $p<0.05$, was used.

each 15 minute sample, then lyso platelet activating factor was assessed after chemical acetylation and AAGPC after alkaline hydrolysis and subsequent acetylation.

Platelet activating factor extraction and purification - Gastric juice lipids were extracted using $80 \%$ ethanol. ${ }^{15}$ These ethanol extracted samples were dried. For high performance liquid chromatography (HPLC) analysis, the dried residues were dissolved in $500 \mu$ l of solution comprising 60:50:5 dichloromethane/methanol/ water (vol:vol). ${ }^{16}$ Samples were then applied to a Microporasil column 3.9 mm ID, $300 \mathrm{~mm}$ length (Waters Associates, Milford, MA, USA) with a flow rate of $1 \mathrm{ml} / \mathrm{min}$. Each $1 \mathrm{ml}$ fraction was dried and resuspended in $50 \mu \mathrm{l}$ of $60 \%$ ethanol and then assayed for platelet aggregating activity.

Assay for platelet activating factor - Washed rabbit platelets were prepared as previously described. ${ }^{17}$ Aspirinated platelets $\left(1.6 \times 10^{8}\right)$ in $300 \mu$ l of Tyrode's solution, containing $2 \cdot 5 \%$ gelatin and the adenosyl diphosphate (ADP) scavenger mixture creatine phosphate $(1 \mathrm{mM})$ and creatine phosphokinase $(10 \mathrm{U} / \mathrm{ml})$ were stirred in an aggregometer (Icare, Marseille, France). Aggregating activity of the samples was measured over the linear portion of the calibration curve obtained with synthetic platelet activating factor.

Assay for lyso platelet activating factor - Lyso platelet activating factor was measured after chemical acetylation into platelet activating factor. ${ }^{15}$ Briefly, the ethanolic extracts were dried under an air stream, mixed with $200 \mu$ l of pyridine and acetic anhydride and kept for 18 hours in the dark, at room temperature. Samples were evaporated and traces of pyridine were removed with dichloromethane. Samples were recovered with $100 \mu$ l of $60 \%$ ethanol and were assayed as described above. The amount of lyso platelet activating factor was calculated as the difference between the quantity of platelet activating factor measured after and before acetylation of the samples.

Assays for AAGPC - AAGPC were measured after alkaline hydrolysis and subsequent acetylation. ${ }^{15}$ Briefly, aliquots of the dried extracts were treated with $0.03 \mathrm{~N} \mathrm{NaOH}$ in methanol for 2 hours at room temperature. The $\mathrm{pH}$ was adjusted to $7 \cdot 0$ with $1 \mathrm{~N} \mathrm{HCl}$ and the mixture was evaporated to dryness. The amount of AAGPC was calculated as the difference between the concentrations of platelet activating factor measured after and before alkaline hydrolysis and acetylation.

Characterisation of platelet activating factor - In addition to its ADP and arachidonic acid independent aggregating activity on rabbit platelets, the lipidic material extracted from gastric juice samples was pooled, dried, and eluted on HPLC. ${ }^{16}{ }^{18}$ The platelet aggregation activity was eluted from 18 to 21 minutes. This material had a retention time typical of platelet activating factor during HPLC analysis using phosphatidylcholine, lysophosphatidylcholine, and synthetic platelet activating factor as standards and was further characterised as platelet activating factor on the basis of the following criteria ${ }^{16-18}$ : (a) its aggregating activity was suppressed in the

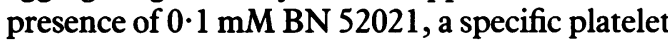
activating factor receptor antagonist $\mathrm{t}^{19}$; (b) and after incubation of the samples with $10 \mu \mathrm{g} / \mathrm{ml}$ phospholipase $\mathrm{A}_{2}$ from hog pancreas; lipase $\mathrm{A} 1$ from $R$ arrhizus $100 \mu \mathrm{g} / \mathrm{ml}$ was without effect. ${ }^{18}$ The efficiency of this procedure averaged $80 \%$ using $\left({ }^{3} \mathrm{H}\right)$ platelet activating factor as internal standard.

\section{GASTRIC ACID MEASUREMENT}

Gastric acid was measured by automated titration using $1 / 10 \mathrm{~N} \mathrm{NaOH}$ to an endpoint $\mathrm{pH}$ of $7 \cdot 0$ and determined as $\mathrm{mmol} / \mathrm{l}$.

\section{CHOLINE MEASUREMENT}

Choline concentration in gastric juice was used as duodenogastric bile reflux marker. ${ }^{20-22}$ We have previously reported that measurement of choline is sufficient to exclude biliopancreatic reflux in the stomach when its amount is below $10 \mu \mathrm{mol} /$ $\mathrm{hr} .{ }^{21}$ The concentration of choline in gastric juice was measured by an enzymatic method as described $^{20}$ : phospholipase D treatment and oxidation by 4-aminophenazone (Biolyon). 


\section{PEPSIN MEASUREMENT}

The proteolytic activity of each 15 minute gastric juice samples was determined by an automatic method using human haemoglobin as substrate ${ }^{21}$ and the concentration was determined as UP/ml.

\section{SIALIC ACID DETERMINATION}

N-Acetylneuraminic acid (NANA), a sialic acid linked to mucus glycoproteins, was determined according to Aminoff. ${ }^{23}$ Briefly, NANA was oxidised by periodic acid $\left(0.9 \mathrm{~N} ; 37^{\circ} \mathrm{C}\right)$, and then this oxidised component was bound to thiobarbituric acid giving a stable chromophore in butanol. The adsorption was read at $549 \mathrm{~nm}$ and compared with a scale of the NANA standard. The results were expressed in $\mu \mathrm{g} / \mathrm{ml}$. The concentration of solubilised NANA in gastric juice was obtained by the difference between total NANA measured after acidic hydrolysis $\left(\mathrm{H}_{2} \mathrm{SO}_{4}\right.$ $0 \cdot 1 \mathrm{~N}, 80^{\circ} \mathrm{C}, 60 \mathrm{~min}$ ) and free NANA measured directly as $\mu \mathrm{g} / \mathrm{ml}^{22}$
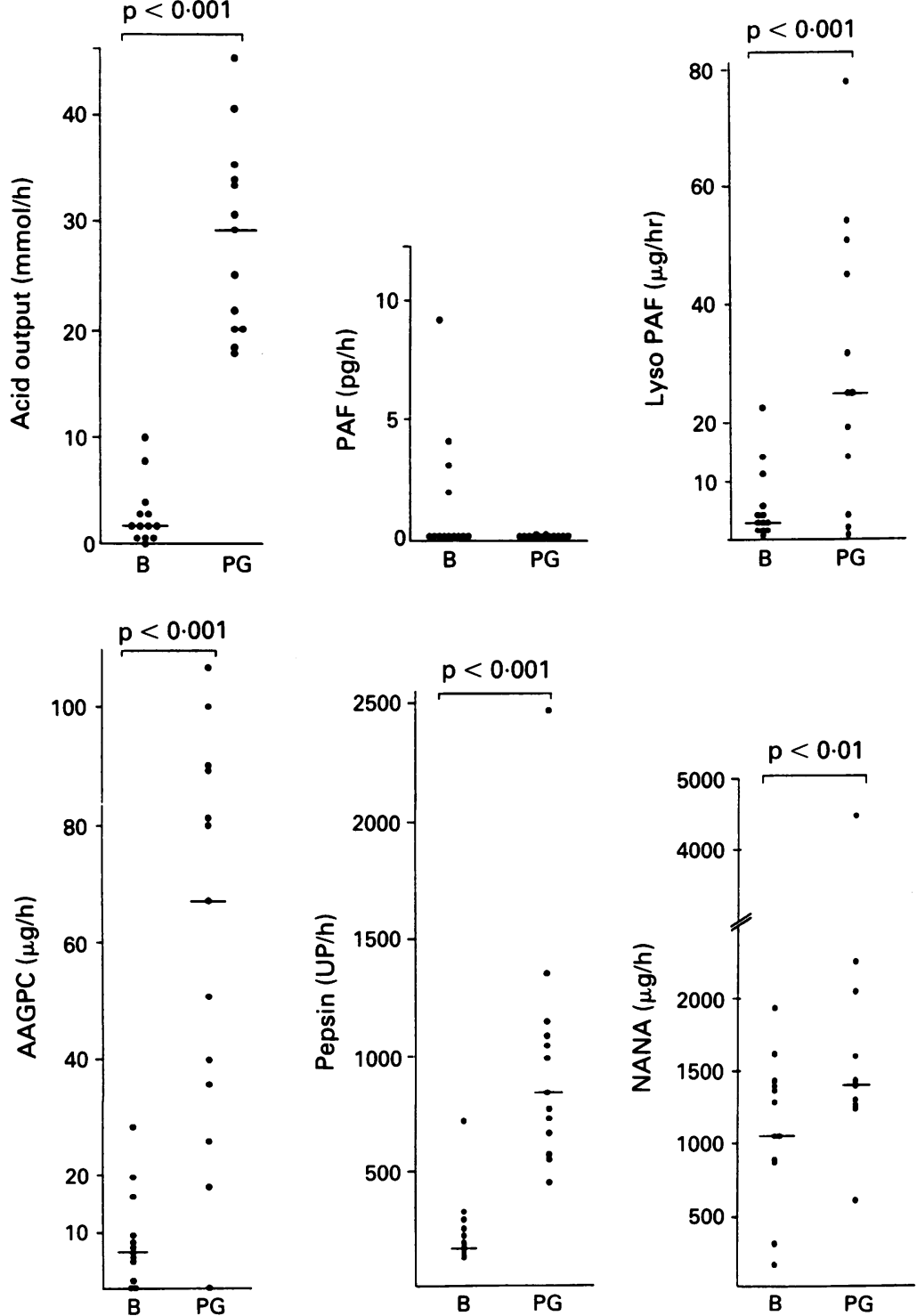

Figure 1: Individual hourly gastric output values of acid, platelet activating factor (PAF), $P A F$ precursors, pepsin, and $N$-acetylneuraminic acid (NANA) are indicated in basal $(B)$ condition and in response to pentagastrin $(P G)$ in healthy volunteers; solid line designates the median. The Student's t paired test was used for the comparison between basal and pentagastrin period.

\section{CALCULATIONS AND STATISTICAL TESTS}

Volume of total gastric juice in basal and under pentagastrin infusion was calculated as the sum of four 15 minute samples in each period (Table) and the hourly output of each substance (platelet activating factor: $\mathrm{pg} / \mathrm{hr}$; lyso platelet activating factor: $\mu \mathrm{g} / \mathrm{hr}$; AAGPC: $\mu \mathrm{g} / \mathrm{hr}$; acid: $\mathrm{mmol} / \mathrm{hr}$; pepsin: pepsin unit UP/hr; NANA: $\mu \mathrm{g} / \mathrm{hr}$; choline: $\mu \mathrm{g} / \mathrm{hr}$ ) was calculated as the sum of four 15 minute rates of secretion; each 15 minute rate having been determiend by multiplication of concentration by the volume of gastric juice aspirated during 15 minutes. All values were expressed as mean (SEM). Statistical analysis were performed with the Student's paired $t$ test, and the Spearman rank correlation tests. To show the concentration pattern in basal and under pentagastrin conditions, we also calculated concentrations of acid, platelet activating factor, platelet activating factor precursors, and NANA as the mean of four 15 minute concentrations for each period, basal and pentagastrin (Table).

\section{Results}

Mean concentrations of platelet activating factor and precursors in gastric juice in basal condition and during pentagastrin infusion are shown in the Table. In the basal condition as well as under pentagastrin infusion choline outputs remained below $10 \mu \mathrm{mol} / \mathrm{hr}$ (mean=1.5 (0.8) and 4 (2) $\mu \mathrm{mol} / \mathrm{h}$, respectively), so that no subject had to be excluded because of duodenogastric bile reflux.

GASTRIC PLATELET ACTIVATING FACTOR PRECURSORS IN BASAL CONDITION AND UNDER PENTAGASTRIN

Lyso platelet activating factor - It was detected in all subjects with amounts ranging from 1 to 23 $\mu \mathrm{g} / \mathrm{h}$ (mean $6 \cdot 1(1 \cdot 8)$ ) in basal condition and increased significantly ( 1 to $77 \mu \mathrm{g} / \mathrm{h}$; mean 31.8 $(6.8) \mu \mathrm{g} / \mathrm{hr}$ ) under pentagastrin infusion (Table and Fig 1).

$A A G P C$ - It was detected in 11 of 13 subjects with amounts ranging from 2 to $35 \mu \mathrm{g} / \mathrm{h}$ (mean $11.5(3))$ in basal condition and increased significantly (10 to $109 \mu \mathrm{g} / \mathrm{h}$; mean $53(9 \cdot 3)$ ) under pentagastrin infusion (Table and Fig 1). Overall, in a given subject, the platelet activating factor and precursors concentrations determined in each 15 minute samples were very close to those obtained from hourly pooled gastric juice.

GASTRIC PLATELET ACTIVATING FACTOR IN BASAL CONDITION AND UNDER PENTAGASTRIN Platelet activating factor was detected in four of 13 subjects $(30 \%)$ in all 15 minute gastric juice samples; hourly amounts ranged from 1 to $8 \mathrm{pg} / \mathrm{h}$ (mean $1.2(0.06))$. In the remaining subjects platelet activating factor was not detected in any 15 minute sample or in hourly pooled gastric juice samples. Platelet activating factor was not detected under pentagastrin infusion in any 15 minute sample or in hourly pooled gastric juice; thus, compared with the basal situation, its secretion decreased in four subjects (Fig 1). 

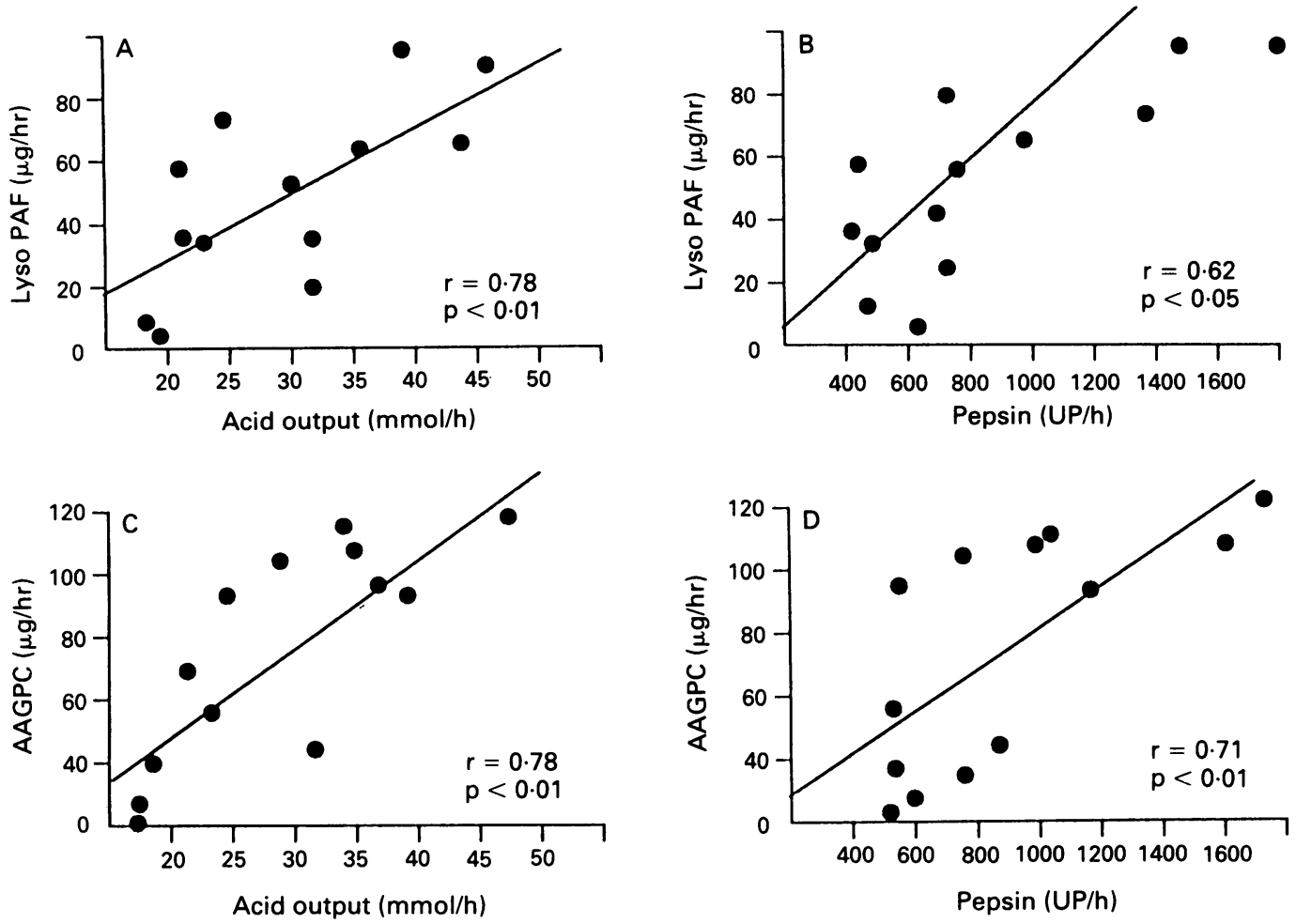

Figure 2: Regression analysis between lyso PAF and acid outputs $(A)$, lyso $P A F$ and pepsin outputs $(B)$, alkylacylglycerophosphocotine $(A A G P C)$ and acid outputs $(C)$, and $A A G P C$ and pepsin outputs $(D)$ in healthy volunteers under pentagastrin infusion. Statistical correlations were performed using the Spearman rank correlation test.

CORRELATION BETWEEN PLATELET ACTIVATING FACTOR PRECURSORS AND ACID, PEPSIN, AND NANA As expected basal acid, pepsin, and NANA outputs $(3.2(0.7) \mathrm{mmol} / \mathrm{h}, 283(53) \mathrm{UP} / \mathrm{h}$, and $1100(140) \mu \mathrm{g} / \mathrm{h}$, respectively) increased significantly under pentagastrin infusion (28 (2.5) $\mathrm{mmol} / \mathrm{h}, 985$ (145) UP/h, and $1763(292) \mu \mathrm{g} / \mathrm{h}$ ), respectively; Fig 1).

Under pentagastrin stimulation, taking all subjects together, the regression analysis showed a significant correlation between lyso platelet activating factor and acid, lyso platelet activating factor and pepsin, AAGPC and acid, AAGPC and pepsin (Fig 2). When hourly gastric outputs were compared, no significant correlation was found between NANA and lyso platelet activating factor $(\mathrm{r}=0.08 ; \mathrm{p}=0.6)$, NANA, and AAGPC $(r=0.45 ; p=0.06)$; again, when concentrations were compared no significant correlation was found between NANA $(\mu \mathrm{g} / \mathrm{ml})$ and lyso platelet activating factor $(\mathrm{ng} / \mathrm{ml})(\mathrm{r}=0.4 ; \mathrm{p}=$ $0 \cdot 19)$ or NANA and AAGPC $(\mu \mathrm{g} / \mathrm{ml})(\mathrm{r}=0.05$; $\mathrm{p}=0 \cdot 86$ ).

\section{Discussion}

In this study, we showed that in healthy volunteers secretion of gastric platelet activating factor precursors increased under pentagastrin infusion. We found a relation between platelet activating factor precursors and acid, and between platelet activating factor precursors and pepsin.

Given the various substances that can activate platelets, it was necessary to show that the platelet aggregating material purified from gastric juice samples was platelet activating factor. To do this, we used experimental criteria to characterise and distinguish it from arachidonic acid, prostaglandin, chollagen, thrombin, or adenosine diphosphate (see Methods). Yet, choline output remained below $10 \mu \mathrm{g} / \mathrm{h}$ showing that lipidic material purified from gastric juice was not of biliopancreatic origin. ${ }^{212426}$ In this study, we preferred choline measurement to a duodenal or pyloric occluding balloon that might induce gastric or duodenal distension.

Platelet activating factor is one of the most potent lipid mediators discovered, which exerts a wide span of cellular and tissular effects ranging from degranulation of inflammatory cells to mucosal ulceration and necrosis. ${ }^{29}$ Platelet activating factor plays a part in the mucosal injury of the gastrointestinal tract in animals. ${ }^{29-12}$ In humans, platelet activating factor has been found in patients with oesophagitis, ulcer gastric, Crohn's disease, and ulcerative colitis by us and others. ${ }^{136-28}$ Until now, however, only a few data pointed to the production of platelet activating factor in physiological processes. ${ }^{29}$ In this study, we found platelet activating factor in four of 13 normal subjects. The concentration of platelet activating factor in this study $(1.2 \mathrm{pg} / \mathrm{h})$ is much lower than that we had previously found ${ }^{13}$ in patients suffering from oesophagitis $(28 \mathrm{pg} / \mathrm{h})$, erosive gastritis $(25 \mathrm{pg} / \mathrm{h})$, and duodenal ulcer $(5 \mathrm{pg} / \mathrm{h})$. The significance of platelet activating factor in the gastric juice of healthy humans is still difficult to analyse. In this study, all subjects were selected on the basis of standard criteria of normality. We can not exclude the possibility, however, of abnormal metabolism of platelet activating factor in four of them. Two of four were smokers (patients 3 and 6 ) suggesting a possible cause of abnormal platelet activating factor metabolism; yet, non-symptomatic 
gastritis related to Helicobacter pylori (H pylori) cannot be excluded in them (or at least, in two non-smokers). Nevertheless, in our previous study performed in 36 symptomatic patients, we showed that neither the concentration of gastric platelet activating factor output or the content of platelet activating factor in the gastric mucosa were significantly related to the inflammatory cell infiltration in the gastric mucosa. ${ }^{13}$ Clearly, whether low gastric platelet activating factor concentration in $30 \%$ normal subjects should be considered as physiological or pathophysiological needs further investigation. $H$ pylori, which is able to generate in vitro platelet activating factor from platelet activating factor precursors, ${ }^{30}$ may be a possible pathophysiological cause of platelet activating factor increase. More than $90 \%$ of patients with duodenal ulcer are carriers of $H$ pylori. All carriers of the bacterium, however, do not suffer from duodenal ulcer. Thus, the role of platelet activating factor should be interpreted considering both $H$ pylori and acid.

The fact that pentagastrin increased platelet activating factor precursors would suggest that platelet activating factor may have a role in the gastric functions, in particular gastric acid secretion. A possible relation between platelet activating factor and gastric acid secretion ${ }^{31-32}$ and platelet activating factor and gastric motility ${ }^{33}$ has already been suggested as a physiological phenomenon in the gastrointestinal tract. Also Wallace and Keenan ${ }^{34}$ have reported that intracolonic administration of platelet activating factor may have a protective role in the gastrointestinal tract in animals.

As platelet activating factor was not detected under pentagastrin infusion, two hypotheses should be discussed concerning the effect of pentagastrin on gastric platelet activating factor synthesis. Firstly, gastrin would exert a direct negative effect on platelet activating factor synthesis. Such a mechanism seems unlikely because platelet activating factor precursors increase under pentagastrin infusion. Alternatively, gastrin might affect enzymes participating in platelet activating factor generation by acid or pepsin. Benveniste et al showed that platelet activating factor was susceptible to lipase $\mathrm{C}$ and $\mathrm{D},{ }^{18}$ and Moreau et $a l^{35}$ reported that pentagastrin could enhance gastric lipase activity in humans. This hypothesis deserves further study as platelet activating factor metabolism in the stomach lumen is unknown. In our previous study of gastric platelet activating factor analysis, gastric juice content seemed to be a more valuable index than mucosal content as platelet activating factor was not detectable in several biopsy specimens. This might be as a result of the weight of endoscopy biopsy samples. The ratio of platelet activating factor/ lyso platelet activating factor/AAGPC in the gastric mucosa was similar to that of gastric juice. For all these reasons, we think that extraction of platelet activating factor and precursors from the gastric mucosa would not give more information than that obtained from gastric juice analyses. Yet, in this study the amount of platelet activating factor $(0.03 \mathrm{pg} / \mathrm{ml}$; $1.2 \mathrm{ng} / \mathrm{h}$ ) is much lower than that of lyso platelet activating factor $(0.09 \mathrm{ng} / \mathrm{ml} ; 6.1 \mu \mathrm{g} / \mathrm{h})$ and AAGPC $(0.14 \mu \mathrm{g} / \mathrm{ml} ; 11.5 \mu \mathrm{g} / \mathrm{h})$ suggesting that platelet activating factor degradation may not be the only source of platelet activating factor precursors under pentagastrin stimulation. Because calcium is increased in gastric epithelial cells $^{36}$ in response to gastrin and the remodelling pathway of platelet activating factor synthesis is activated by calcium, ${ }^{37-39}$ platelet activating factor precursors seem to be related to the calcium increase in gastric cells.

Acid and pepsin are released from gastric epithelial cells. NANA, which represents the sialic acid linked to mucus glycoproteins, ${ }^{40}$ illustrates glycoprotein erosion under pentagastrin stimulation. ${ }^{22}$ As the regression analysis showed a significant correlation between platelet activating factor precursors and both acid and pepsin but no significant correlation between platelet activating factor precursors and NANA, we suggest that platelet activating factor precursors would not result from degraded gastric mucin. In conclusion, the rise in platelet activating factor precursors induced by pentagastrin correlates with acid and pepsin. This correlation argues for the possibility of synthesis of platelet activating factor precursors in cells sensitive to gastrin stimulation.

1 Benveniste J, Henson PM, Cochrane CG. Leukocyte dependent histamine-release from rabbit platelets: the role of IgE, basophils and platelet-activating factor. $₹$ Exp Med of IgE, basophils and

2 Benveniste J. Paf-acether, and ether phospholipid with biological activity. In: Karnovsky ML, Leaf A, Bolis LC, eds. Biological membranes. New York: Liss, 1988: 73-85.

3 Foa R, Bussolino F, Ferrando ML, Guarini A, Tetta C, Mazzone R, et al. Release of platelet-activating factor in human leukemia. Cancer Res 1985; 45: 4483-5.

4 Mencia-Huerta JM, Lewis RA, Razin E, Austen KF. Antigeninitiated release of platelet-activating factor (paf-acether) from mouse bone marrow-derived mast cells (paf-acether) monoclonal IgE. F Immunol 1983; 131: 2958-64.

5 Camussi G, Aglietta M, Malavasi F, Tetta C, Piacibello W, Sanvio F, et al. The release of platelet-activating factor from human endothelial cells in culture. $\mathcal{F}$ Immunol 1983; 131: human endot

6 McIntyre TM, Zimmerman GA, Satoh K, Prescott SM. Cultured endothelial cells synthesize both platelet-activating factor and prostacyclin in response to histamine, bradykinin, and adenosine triphosphate. $\mathcal{F}$ Clin Invest 1985; 76: $271-80$.

7 Lee TC, Lenihan DJ, Malone B, Roddy LL, Wasserman SI. Increased biosynthesis of platelet-activating factor in activated human eosinophils. I Biol Chem 1985; 259: 5526-30.

8 Ninio E, Mencia-Huerta JM, Heymans F, Benveniste J. Identification of phospholipid platelet-activating factor (1-O-alkyl-2-acetyl-sn-glycero-3-phosphocholine) in human amniotic fluid and urine. Biochem Biophys Res Commun amniotic fluid and

9 Snyder F. Platelet-activating factor and related acetylated lipids as potent biologically active cellular mediators. $A m \mathcal{F}$ Physiol 1990; 259: C697-708.

10 Rosam AC, Wallace JL, Whittle BJR. Potent ulcerogenic actions of platelet-activating factor on the stomach. Nature 1986; 319: 54-6.

11 Prescott SM, Zimmerman GA, McIntyre TM. Platelet activating factor (Minireview). f Biol Chem 1990; 265: $17381-4$.

12 Wallace JL. Lipid mediators of inflammation in gastric ulcer. Am ₹ Physiol 1990; 258: G1-11.

13 Sobhani I, Denizot Y, Vissuzaine JC, Vatier J, Benveniste J, Lewin MJM, et al. Significance and regulation of gastric pafLewin MJM, et al. Significance and regulation of gastric

14 Sobhani I, Bado A, Denizot Y, Lewin MJM. Secretion of pafacether in cat. Gastroenterology 1990; 98: A127.

15 Jouvin-Marche E, Ninio E, Beaurain G, Tence M, Niaudet P, Jouvin-Marche E, Ninio E, Beaurain G, Tence M, Niaudet P,
Benveniste J. Biosynthesis of PAF-acether (platelet-activatBenveniste J. Biosynthesis of PAF-acether (platelet-activat-
ing factor): VII - Precursors of PAF-acether and acetyling factor): VII - Precursors of PAF-acether and acetyltransferase acti

16 Tence M, Polonsky J, Le Couedic JP, Benveniste J. Release, purification, and characterization of platelet-activating factor (PAF). Biochimie 1980; 62: 251-9.

17 Caxenave JP, Benveniste J, Mustard FJ. Aggregation of rabbit platelets by platelet-activating factor is independant of the release reaction and the arachidonate pathway and inhibited by membrane-active drugs. Lab Invest 1979; 41: 275-85. 
18 Benveniste J, Le Couedic JP, Polonsky J, Tence M. Structural analysis of purified platelet-activating factor by lipases. analysis of purified pla

19 Korth R, Benveniste J. BN52021 displaces (3H)pac-acether, and inhibits binding to intact platelets. Eur $\mathcal{f}$ Pharmacol 1987; 142: 331-41.

20 Vatier J, Poitevin C, Vitre MT, Mignon M. Caractérisation et évaluation du caractère pathogène du reflux duodénogastrique par la mesure de la choline et de l'acide sialique intragastrique chez le sujet normal et l'ulcéreux duodénal. Gastroenterol Clin Biol 1988; 12: 207-13.

21 Vatier J, Sauvage M. Lewin MJM, Bonfils S. Approche d'une determination automatique de l'activite proteolytique du suc gastrique dans les conditions de la vitesse intiale de la réaction. Biol Gastroenterol 1975; 8: 107-15.

22 Vatier J, Poitevin C, Mignon M. Sialic acid content and proteolytic activity in gastric juice in humans. Dig Dis $S_{c i}$ proteolytic activity

23 Aminoff $D$. Methods for quantitative stimation of N-Acetylaneuraminic acid and their applications to hydrolysate of sialomucoids. Biochem f 1961; 81: 384-91.

24 Johnson AG, McDermott SJ. Lysolecithin a factor in the pathogenesis of ulceration. Gut 1974; 15: 710-13.

25 Schumplick V, Bagemann F, Bandomer G, Grossner D, Doehen $M$. Intragastrale gallensauren und lysolecithin bei klinischer stressulkusgefhardung. Disch Med Wochenscher 1978; 103: 735-7.

26 Sobhani I, Hochlaff S, Denizot Y, Rene E, Lewin MJM, Mignon M. Raised concentrations of platelet activating factor in colonic mucosa of Crohn's disease patients. Gut 1992; 33: 1220-5.

27 Eliakim R, Karmeli F, Razin E, Rachmilewitz D. Role of platelet-activating factor in ulcerative colitis: Enhanced production during active disease and inhibition by sulfasalazine and prednisolone. Gastroenterology 1988; 95: 1167-72.

28 Kald B, Olaison G, Sjödahl R, Tagesson C. Novel aspect of Crohn's disease: Increased content of platelet-activating factor in ileal and colonic mucosa. Digestion 1990; 46: 199-204.
29 Harper MJK. Platelet-activating factor. A paracrine factor in preimplantation stages of reproduction. Biol Reprod 1989 40: $907-13$.

30 Denizot Y, Sobhani I, Rambaud JC, Lewin MJM, Thomas Y, Benveniste J. Paf-acether synthesis by Helicobacter Pylori. Gut 1990; 31: 1242-5.

31 Nogami M, Suko M, Miyamoto T. The effect of platelet activating factor on $\left({ }^{14} \mathrm{C}\right)$ aminopyrine uptake by isolated guinea pig parietal cells. Biochem Biophys Res Commun 1990 168: $1047-52$.

32 Cucala M, Wallace JL, Salas A, Guarner F, Rodriguez R, Malagelada JR. Central regulation of gastric acid secretion by platelet-activating factor in anesthesized rats. Prostaglandins 1989; 37: 275-85.

33 Esplugues JV, Whittle BJR. Mechanisms contributing to gastric motility changes induced by PAF-acether and endogastric motility changes induced by PAF-acether and endo-
toxin in rats. A m f P hysiol 1989; 256: G275-82.

34 Wallace JL, Keenan CM. Leukotriene B4 potentiates colonic ulceration in the rat. Dig Dis Sci 1990; 35: 622-9.

35 Moreau H, Sauniere JF, Gargouri Y, Pieroni G, Verger R Human gastric lipase, variations induced by gastrointestina hormones and by pathology. Scand F Gastroenterol 1988; 23 . 1045-8.

36 Walsh J. Gastrointestinal hormones. In: Johnson LR, ed. Physiology of the gastrointestinal tract. Vol 1. New York: Raven Press, 1987: 181-225.

37 Waykle RL, Malone B, Snyder F. Enzymatic synthesis of 1-alkyl-2-acetyl-sn-glycero-3-phosphocholine, a hypotensive and platelet-activating lipid. $\mathcal{F}$ Biol Chem 1980; 255 $10256-60$.

38 Touqui L, Shaw M, Dumarey C, Jacquemin C, Vargaftig BB The role of $\mathrm{Ca} 2+$ in regulating the catabolism of paf-acether The role of $\mathrm{Ca} 2+$ in regulating the catabolism of

39 Kawasaki T, Snyder F. The metabolism of lyso plateletactivating factor by a calcium dependent lysophospholipase $\mathrm{D}$ in rabbit kidney medulla. Biochim Biophys Acta 1987; 290. 85-93.

40 Allen A, Pearson JP, Venables CW. The glycoprotein from human gastric mucus gel and its breakdown by pepsin. f Physiol 1979; 293: 30P 